\title{
Pelatihan I bu Pembelajar : Upaya Peningkatan Kapasitas I bu Dalam Mengasuh Anak Di Desa Pantai Bahagia Kecamatan Muara Gembong Kabupaten Bekasi J awa Barat
}

\author{
Meilanny Budiarti Santoso, Dessy Hasanah Siti Asiah \\ Meilannybudiarty13@gmail.com, Dessyhasanahsitiasiah@yahoo.com
}

\begin{abstract}
ABSTRAK
Di tengah banyaknya tantangan untuk dapat membesarkan anak dengan baik dan sesuai dengan harapan orang tua, para orang tua pun dihadapkan pada kenyataan maraknya berbagai permasalahan yang menimpa anak-anak. Ibu sebagai orang tua yang lebih banyak menghabiskan waktu bersama anak terutama pada saat anak berusia masih kecil dan sebagai sosok yang memegang peranan sebagai pengasuh dan pendidik di dalam keluarga menjadikan ibu memegang peranan penting dalam keluarga. Dalam situasi demikian, seorang ibu dituntut memiliki pengetahuan mengenai tahapan perkembangan anak. Faktor penting lainnya dalam pengasuhan adalah parenting self-efficacy yang dimaknai sebagai perkiraan orang tua terhadap kompetensi yang dimilikinya dalam perannya sebagai orang tua, atau persepsi orang tua terhadap kemampuannya untuk mempengaruhi perilaku dan perkembangan anak secara positif.

Berdasarkan situasi tersebut, maka kegiatan pelatihan peningkatan kapasitas ibu menjadi seorang pembelajar dipandang sangat perlu untuk dilakukan, agar para ibu memiliki pengetahuan, sikap dan keterampilan yang terus berkembang dalam mengasuh dan mendidik anak-anaknya.

Kata kunci: Ibu pembelajar, peningkatan kapasitas ibu, tahap perkembangan anak, parenting self-efficacy
\end{abstract}

\begin{abstract}
In the midst of the many challenges to be able to raise children well and in accordance with the expectations of parents, the parents were faced with the fact of the rampant various problems that befell children. Mothers as parents who spend more time with children, especially when the child was a child and as a figure who plays the role of caregivers and educators in the family to make mothers play an important role in the family. In such a situation, a mother is required to have knowledge of the stages of child development. Another important factor in parenting is the parenting self-efficacy that is interpreted as an estimate of the parents of the competence it has in its role as a parent, or parental perceptions of its ability to influence the behavior and development of children positively.

Based on the situation, the training activities to improve the capacity of mothers to be a learner is very necessary to be done, so that mothers have the knowledge, attitudes and skills that continue to grow in nurturing and educating their children.
\end{abstract}

Keywords: mother learner, mother capacity building, child development stage, parenting self-efficacy

\section{PENDAHULUAN}

Anak adalah tunas harapan orang tua dan juga merupakan generasi penerus suatu bangsa, maka tak berlebihan kiranya bila dinyatakan bahwa suatu bangsa akan kokoh dan tangguh apabila anak-anak sebagai generasi penerusnya memiliki kepribadian dan mentalitas yang positif dan kuat serta berperilaku sesuai dengan yang diharapkan oleh orang tua mereka. Sejalan dengan hal tersebut, pemerintah tengah gencar melaksanakan berbagai program pembangunan sumber daya manusia, khususnya terkait dengan proses peningkatan kualitas generasi penerus bangsa.
Di sisi lain, berbagai macam tantangan dan permasalahan datang menghadang dan bahkan dapat menghancurkan tumbuh kembang dan kualitas generasi penerus bangsa. Berbagai macam bentuk tantangan dan permasalahan yang dihadapi oleh anakanak bangsa ini dapat bersumber dari dalam diri anak-anak itu sendiri, seperti keterbatasan yang dimiliki oleh anak ataupun tantangan dan permasalahan yang datang dari kondisi keluarga, lingkungan teman sepermainan anak, lingkungan sekolah ataupun dari lingkungan masyarakat seperti nilai-nilai kurang baik yang berkembang dalam interaksi sosial anak, perkataan kasar, perilaku 
menentang nilai-nilai ataupun ajaran kebaikan dan menentang nasihat orang tua.

Situasi yang demikian menjadi lebih buruk dengan terjadinya globalisasi yang tidak dapat dibendung, salah satunya pengaruh negatif dari teknologi canggih di mana penyebarluasan informasi menjadi begitu cepat, bahkan dapat diakses melalui telephone genggam, maraknya games online yang dimainkan oleh anak-anak menambah buruk keadaan. Tentunya games online menyuguhkan berbagai kesenangan dalam permainan, sehingga membuat anak menghabiskan banyak waktu untuk bermain, hingga menjadi lupa dan bahkan tidak mau untuk belajar serta membuat anak menjadi cenderung emosional. Situasi demikian sering kali menjadi sumber konflik antara anak dengan ibunya ataupun dengan anggota keluarga lainnya.

Dalam lingkungan yang lebih luas, kejahatan terhadap anak pun semakin banyak terjadi di tengah kehidupan bermasyarakat, sehingga peran orang tua menjadi semakin kompleks dalam menjaga, mengasuh dan mendidik anak agar anak dapat tetap aman dan berkualitas. Sejalan dengan hal tersebut, maka proses pengasuhan dan pendidikan anak di dalam keluarga menjadi kunci utama keberhasilan tumbuh kembang anak ke arah yang positif dan sesuai dengan norma-norma di dalam masyarakat, karena pengasuhan dan pendidikan anak di dalam keluarga merupakan pondasi dalam proses pembentukan kepribadian dan mental bagi diri anak.

Ibu sebagai orang tua yang lebih banyak menghabiskan waktu bersama anak terutama pada saat anak berusia masih kecil dan sebagai sosok yang memegang peranan sebagai pengasuh dan pendidik di dalam keluarga menjadikan ibu memegang peranan penting dalam keluarga (Santoso dan Batubara, 2017). Dalam situasi demikian, seorang ibu dituntut memiliki pengetahuan mengenai tahapan perkembangan anak. Di sisi lain, seorang ibu pun seringkali memiliki harapan dan target yang ingin dicapai terkait dengan masa depan anak-anaknya. Dengan demikian, seorang ibu diharapkan dapat mentranfer pengetahuan, sikap dan keterampilan yang baik dalam mengasuh dan mendidikan anak serta lebih gencar menanamkan nilai-nilai kebaikan kepada anak-anak mereka dengan berbagai macam metode yang dapat dipahami dan menarik bagi anak, sehingga anak dapat melaksanakannya dalam kehidupan.

Hal ini menjadi penting untuk diperhatikan, karena berdasarkan riset yang dilakukan oleh Santoso dan Batubara (2017) terhadap ibu-ibu yang memiliki anak usia sekolah dasar, menunjukkan temuan bahwa seringkali terjadi misunderstanding antara ibu dan anak terkait proses parenting yang dilakukan oleh ibu. Di satu sisi ibu merasa telah memberi penjelasan mengenai apa yang harus dilakukan oleh anak ataupun telah memberikan nasihat kepada anak pada saat anak melakukan kesalahan, sedangkan di sisi lain anak tidak dapat mengerti apa yang dikatakan oleh ibunya, karena bagi anak penjelasan ataupun nasihat yang diberikan oleh ibunya itu bersifat abstrak, sehingga sulit untuk dimengerti terlebih untuk diterapkan dalam perilaku kesehariannya.

Namun, sebagaimana kita pahami bersama bahwa dalam kehidupan ini, tidak ada sekolah khusus untuk menjadi orang tua yang baik. Ketika seseorang berkeluarga dan menjadi orang tua bagi anak-anaknya, maka semua aktivitas berkeluarga berjalan secara alamiah sebagaimana pada umumnya dan semua hal dianggap biasa saja. Dalam situasi demikian, seringkali orang tua muda dalam keluarga barunya hanya mengembangkan pola pengasuhan dan pendidikan bagi anakanaknya sebagaimana dulu mereka diasuh dan dididik oleh orang tua yang membesarkan mereka. Hal ini tentunya tidak cukup untuk dijadikan sebagai bekal bagi orang tua zaman sekarang ini, khususnya bagi seorang ibu muda dalam mengasuh dan mendidikan anakanaknya di tengah berbagai macam tantangan dan permasalahan yang telah diuraikan sebelumnya.

Berdasarkan situasi tersebut, maka kegiatan pelatihan peningkatan kapasitas ibu 
untuk menjadi seorang ibu pembelajar dipandang sangat perlu untuk dilakukan, agar para ibu memiliki pengetahuan, sikap dan juga keterampilan yang terus berkembang dalam mengasuh dan mendidik perkembangan anak-anaknya, sehingga diharapkan dapat memberikan dampak yang positif pada pembentukan generasi yang lebih baik pada masa yang akan datang.

\section{Perkembangan Anak}

Pola perilaku sosial ataupun perilaku lainnya pada seorang anak dibina pada masa kanak-kanak awal atau masa pembentukan dan akan menghasilkan pengalaman sosial awal yang sangat menentukan kepribadian setelah anak menjadi dewasa. Proses pengasuhan anak pada masayarakat merupakan faktor yang sangat penting. Pengasuhan anak adalah bagian dari sosialisasi tentang bagaimana anak dibimbing untuk dapat memiliki kepribadian dan perilaku yang sesuai dengan tuntutan kebudayaan masyarakatnya.

Seorang bayi dapat diibaratkan seperti bahan mentah yang di satu sisi ada aspek tumbuh kembang anak yang sedang terjadi dengan sendirinya dan di sisi lain ada aspek tumbuh kembang lainnya yang harus dibantu untuk dikembangkan oleh orang lain. Bayi membutuhkan perawatan dan perlindungan dari orang tuanya. Seorang ibu yang melahirkan atau orang lain yang betanggung jawab membesarkan anak, pada tahap pertama perkembangannya, berperan besar memberikan corak awal kepribadian yang kemudian akan terlihat pada tahap perkembangan anak berikutnya.

Sesungguhnya, jika kita memandang persoalan dilihat dari pekembangan organisma manusia, maka dapat dikatakan bahwa periode janin (feotal) pada manusia berlangsung terus sampai dengan sekitar tahun pertama sesudah kelahiran. Bayi manusia mengalami perkembangan yang penting dan berlangsung setelah ia keluar dari kandungan. Pada masa tersebut, bayi manusia itu tidak hanya sudah berada "dalam" dunia luar; ia juga sudah mempunyai hubungan timbal balik dengan lingkungan sekitarnya.

Menurut Erikson (1959), tahap perkembangan manusia semasa hidupnya terdiri dari 8 (delapan) tahap kehidupan. Erikson melihat proses sosialisasi selama hidup manusia, dimulai dari kelahiran dan berlanjut sampai usia tua. Setiap tahap merupakan masa-masa yang menentukan dalam perubahan psikologis, dan secara tetap mengalami perubahan sesuai dengan situasi sosial yang dihadapinya. Berbagai tahapan perkembangan anak tersebut adalah sebagai berikut:

1) Tahap Pertama, pada saat bayi (0-1 Tahun)

Seorang bayi sepenuhnya tergantung pada orang dewasa. Emosi bayi akan berkembang bersamaan dengan kualitas pengasuhan ibu. Kalau seorang ibu secara konstan mencintai dan memenuhi kebutuhan fisiknya, bayi tersebut membentuk perasaan aman dan percaya.

2) Tahap Kedua, pada masa kanak-kanak awal (2-3 tahun)

Pada masa ini anak-anak belajar berjalan, berbicara, mempegunakan tangannya untuk melakukan hal lain. Mereka mulai memilih sendiri, mengungkapkan keinginannya. Kalau anak mendapat dukungan dari orang tua, mereka akan berhasil, merasa dirimampu. Kalau dihambat, mereka menjadi ragu-ragu dan merasa malu dalam berhubungan dengan orang lain.

3) Tahap Ketiga, tahap bermain (4 atau 5 tahun).

Pada usia ini anak mulai berhayal dan bermain peran orang dewasa. Apabila merekadapat mendapat celaan, dan cemoohan akan membentuk perasaan bersalah pada dirianak itu. Bila mendapat dukungan anak itu akan membentuk inisiatif individu.

4) Tahap Keempat, tahap usia sekolah (6 - 11 tahun)

Pada tahap ini dunia anak meluas, banyak ketrampilan baru dipelajari, rasa percaya diri besar/diperbesar 
dengan mendapat pengakuan melalui pencapaian keberhasilan.

5) Tahap Kelima, masa remaja (12- 18 tahun)

Pada tahap ini remaja mengembangkan identitas pribadi melalui interaksi dengan oranglain. Kemampuan meraih suatu keberhasilan, merupakan kesinambungan dari masalampau, masa sekarang dan masa yang akan datang. Ketidak mampuan untuk menggabungkan bermacam-macam peran kedalam satu pribadi, akan menghasilkan kekacauan peran.

Dalam hal ini Hurlock (1997: 26-28) menekankan bahwa, usia anak pada 2 sampai 5, adalah tahun-tahun yang paling penting. Karena, pada tahap-tahap inilah periode diletakkannya dasar perilaku kompleks yang dibangun sepanjang kehidupan anak. Dasar untuk pola sikap dan perilaku diletakan secara dini, yaitu ketika lingkungan terbatas pada rumah dan kontak sosial umumnya terdapat diantara anggota keluarga, maka dasar pembentukan pola sikap dan perilaku ini tumbuh dari rumah. Jadi pada masa-masa usia awal ini, keluarga mempunyai peran yang sangat besar dan penting untuk membentuk sikap dan perilaku seorang anak. Bahkan dengan bertambah besarnya anak dan meningkatnya waktu yang dihabiskan oleh anak dengan anggota kelompok teman sebayanya, dengan lingkungan tempat tinggal dan sekolahnya, maka pengaruh keberadaan pola sikap dan pola perilaku yang telah terbentuk di dalam rumah akan tetap tampak nyata pada diri anak.

Dasar awal cenderung bertahan dan mempengaruhi sikap dari perilaku anak sepanjang hidupnya. Hal ini dikarenakan dasar awal cepat berkembang menjadi pola kebiasaan, tidak jadi soal apakah hal itu baik atau buruk, menguntungkan atau merugikan dalam penyesuaian. Seluruhnya ini akan mempunyai pengaruh sepanjang hidup dalampenyesuaian pribadi dan sosial anak tersebut.

Dasar untuk pola sikap dan perilaku diletakan secara dini yaitu ketika lingkungan hampir terbatas pada rumah dan kontak sosial umumnya terdapat diantara anggota keluarga, maka dasar ini tumbuh dari rumah. Jadi pada masa-masa usia awal ini, keluarga mempunyai peran yang sangat besar dan penting untuk membentuk sikap dan perilaku seorang anak. Bahkan dengan bertambah besarnya anak dan meningkatnya waktu yang dihabiskan dengan anggota kelompok teman sebaya, di lingkungan tempat tinggal dan sekolah, pengaruh rumah pada dasar awal tetap akan nyata.

Dasar awal cenderung bertahan dan mempengaruhi sikap dari peilaku anak sepanjang hidupnya. Hal ini dikarenakan dasar awal cepat berkembang menjadi pola kebiasaan, tidak jadi soal apakah hal itu baik atau buruk, menguntungkan atau merugikan dalam penyesuaian. Seluruhnya ini akan mempunyai pengaruh sepanjang hidup dalam penyesuaian pribadi dan sosial anak.

\section{Parenting Self-Efficacy}

Salah satu faktor yang berpengaruh terhadap perilaku pengasuhan yang dilakukan oleh orang tua adalah parenting self-efficacy yang didefinisikan sebagai persepsi orang tua terhadap kemampuan mereka dalam mempengaruhi perilaku dan perkembangan anak secara positif.

Parenting self-efficacy merupakan salah satu bagian dari aspek kognitif dalam kompetensi pengasuhan. Parenting self-efficacy didefinisikan sebagai perkiraan orang tua terhadap kompetensi yang dimilikinya dalam perannya sebagai orang tua, atau persepsi orang tua terhadap kemampuannya untuk mempengaruhi perilaku dan perkembangan anak secara positif (Coleman \& Karraker, 2000). Parenting self-efficacy yang tinggi berhubungan erat dengan kapasitas orang tua dalam menyediakan lingkungan pengasuhan yang adaptif, menstimulasi, dan mendorong perkembangan (Donovan, Leavitt, \& Walsh, 1997).

Dari berbagai penelitian ditemukan bahwa parenting self-efficacy yang tinggi berkaitan erat dengan kapasitas orang tua untuk menyediakan lingkungan pengasuhan anak yang adaptif, menstimulasi, dan mendorong perkembangan anak. Sebaliknya, parenting self-efficacy yang rendah berhubungan dengan depresi yang dialami orang tua, perilaku defensif dan mengontrol, 
kemunculan gangguan perilaku pada anak, persepsi orang tua bahwa anak memiliki perilaku yang sulit, stress, dan gaya coping yang pasif. Parenting self-efficacy yang rendah juga berkaitan dengan kecenderungan orang tua untuk fokus pada kesulitan dalam hubungan antara suami dan istri, afeksi yang negatif, tingkat stress yang meningkat, perasaan tidak berdaya dalam peran sebagai orang tua, dan penggunaan teknik pendisiplinan dengan hukuman (Coleman \& Karraker, 2000).

Self-efficacy didefinisikan sebagai keyakinan seseorang tentang kemampuan yang dimilikinya dalam mengarahkan performansinya yang kemudian berpengaruh terhadap berbagai kejadian dalam kehidupan mereka (Bandura, 1997). Self-efficacy tidak hanya memiliki pengaruh langsung terhadap pemilihan aktivitas dan settingnya, namun melalui harapan terhadap keberhasilan, efficacy dapat mempengaruhi usaha coping yang dilakukan seseorang.

Penelitian yang dilakukan oleh Salonen (2009) menyimpulkan bahwa parenting selfefficacy dipengaruhi oleh kondisi dan sifat orang tua, kondisi dan sifat anak, dan kondisi lingkungan. Di antara kondisi dan sifat orang tua yang juga diteliti memiliki pengaruh kepada parenting self-efficacy adalah coping, perubahan dalam hidup, pendidikan, usia, status pernikahan, dan penghasilan keluarga. Selain itu, Holloway dan Behrens (2002) mengatakan bahwa urutan kelahiran ibu dalam keluarganya berhubungan dengan parenting self-efficacy. Ibu yang merupakan anak yang lebih tua dalam keluarga memiliki peran dan tanggung jawab dalam membantu orang tuanya menjaga adik-adiknya, sehingga diharapkan memiliki keyakinan yang lebih baik ketika menjadi orang tua. Beberapa penelitian menghasilkan bahwa kondisi dan sifat anak yang mempengaruhi parenting selfefficacy adalah temperamen anak, usia anak, serta kesehatan dan kematangan anak. Lingkungan yang memberikan motivasi dan dukungan kepada orang tua juga bisa mempengaruhi parenting self-efficacy, salah satu contohnya adalah keluarga yang sehat dan efektif.

Dengan demikian, upaya peningkatan kapasitas ibu dalam melakukan parenting self-efficacy harus terus dilakukan agar ibu dapat menjalankan fungsi pengasuhan pada anak-anaknya dengan lebih baik lagi.

\section{METODE}

Pelatihan Ibu Pembelajar; Upaya Peningkatan Kapasitas Ibu Dalam Mengasuh Anak Di Desa Pantai Bahagia Kecamatan Muara Gembong Kabupaten Bekasi Jawa Barat ini dilakukan dengan menggunakan metodologi pelatihan andragogi, yang mensyaratkan peserta pelatihan diposisikan sebagai orang dewasa dan didorong untuk berperan aktif dalam setiap tahapan pelatihan. Baik melalui metode brainstrorming menganai permasalahan yang dihadapi dan juga metode sharing pengalaman diantara sesama peserta pelatihan dan juga dari fasilitator pelatihan. Hal ini bertujuan agar peserta pelatihan dapat melihat segala sesuatu terkait dengan permasalahan yang sedang dihadapi dari sudut pandang yang berbeda.

\section{PEMBAHASAN}

Kegiatan Pelatihan Ibu Pembelajar; Upaya Peningkatan Kapasitas Ibu Dalam Mengasuh Anak Di Desa Pantai Bahagia Kecamatan Muara Gembong Kabupaten Bekasi Jawa Barat ini dilaksanakan bertepatan dengan kegaitan Supercamp Universitas Padjadjaran pada tahun 2017. Lokasi desa Pantai Bahagia berbatasan dengan wilayah Jakarta. Penduduk dapat menggunakan speed boat untuk sampai ke wilayah Jakarta. Mobilitas penduduk Desa Pantai Bahagia cukup tinggi, hal ini dimudahkan selain transportasi laut prasarana darat dalam hal ini jalan raya sudah beraspal. Mata pencaharian penduduk sebagian besar sebagai petambak udang dan nelayan. Tingkat ekonomi penduduk cukup baik hal dapat dilihat dari fisik bangunan rumah rumah penduduk dan gaya hidup dalam hal berbusana dan penampilan sehari hari. Dapat dikatakan bahwa penduduk Desa Pantai Bahagia bukan termasuk kedalam kelompok nelayan yang miskin. Hal ini dimungkinkan karena mata pencaharian yang dihasilkannya adalah udang, kepiting, ikan bandeng di jual ke Jakarta dan Bandung. Bahasa yang digunakan 
untuk komunikasi sehari hari adalah bahasa Indonesia. Desa Pantai Bahagia termasuk wilayah Jawa Barat, tetapi penduduknya lebih berorientasi ke Jakarta. Mereka tidak atau kurang mengerti bahasa Sunda.

Peserta Kegiatan Pelatihan Ibu Pembelajar terdiri dari beragam peserta yang terdiri dari para ibu dengan beragam usia dan latar belakang pendidikan, yaitu ibu-ibu dengan usia muda yang baru mempunyai anak, ibu-ibu yang sudah usia lanjut dan mempunyai cucu dan bahkan ibu-ibu yang sudah menjadi buyut. Keragaman usia pada peserta pelatihan ini dikarenakan kegiatan Pelatihan Ibu Pembelajar ini diselenggarakan bertepatan dengan kegiatan pengajian ibu-ibu, pesertanya adalah ibu-ibu yang keragaman usia. Rata-rata bahkan hampir semua para ibu adalah ibu rumah tangga dan hanya 1-2 orang ibu saja yang bekerja sebagai penambak.

Semua ibu peserta pelatihan belum pernah mendapatkan pelatihan parenting skills sebelumnya. Namun demikian, ada beberapa peserta pelatihan yang dapat menjawab dan menjelaskan apa itu parenting skills, para peserta sudah mengetahui harus bagaimana cara mengasuh anak yang baik, mengetahui tahap perkembangan anak walaupun masih sangat bervariatif tingkat pemahamannya. Pemahaman para prserta pelatihan sangat didasarkan pada pengalaman dan pemahaman masing-masing para Ibu dalam proses pengasuhan yang mereka lakukan sehari-hari di rumah.

Menurut para peserta pelatihan, tanggung jawab ibu dalam keluarga sangat berat, karena harus mengandung anak, melahirkan, mendidik dan mengurus anak, memasak, mengurus keluarga/rumah tangga, dan mencari uang. Tidak bisa sembarangan dan asal-asalan untuk menjadi seorang ibu, karena tanggung jawab ibu sangat berat dan banyak di dalam keluarga. Di sisi lain, para peserta pun berpendapat bahwa keberhasilan anak dimulai dari orang tuanya.

Seorang ibu harus benar dalam mendidik anak dan keluarganya, sehingga seorang ibu harus terus belajar dan menjadi pembelajar. Di zaman sekarang ini, semakin banyak tantangan yang harus dihadapi oleh seorang ibu dalam mendidik dan mengurus seorang anak, mulai dari pergaulan anak yang semakin bebas dan sulit dikendalikan oleh orang tua, tayangan televisi yang semakin tidak mendidik, permainan dalam handphone yang semakin menarik hingga mengganggu anak untuk belajar, faktor lingkungan yang tidak kondusif dan cenderung negatif bagi perkembangan anak, juga faktor pertemanan anak yang tidak baik dan dapat mengkontaminasi pikiran, sikap dan tindakan anak.

Berikut ini harapan orang tua (ibu) terhadap anak-anaknya, yaitu:

1. Memiliki anak yang baik dan sholeh/sholehah

2. Memiliki anak yang taat shalat lima waktu

3. Memiliki anak yang pandai membaca Al-Qur'an

4. Memiliki anak yang rajin belajar

5. Memiliki anak yang taat dan menurut pada orang tua

6. Memiliki anak yang sopan dan santun

7. Memiliki anak yang berakhlak mulia

8. Memiliki anak yang berpendidikan tinggi

9. Memiliki anak yang sayang pada orang tua dan keluarga

10. Memiliki pekerjaan yang baik dan sukses dalam pekerjaan

11. Memiliki anak yang jujur

12. Memiliki anak yang bercita-cita tinggi dan dapat mencapai cita-citanya Untuk bisa mencapai berbagai harapan tersebut adalah dengan cara:

1. Memberikan perhatian dan perlindungan pada anak

2. Mengajarkan hal-hal yang baik dan positif pada anak

3. Memperkenalkan nilai-nilai dan norma-norma dalam masyarakat

4. Mengajarkan nilai-nilai agama

5. Memberikan contoh dan teladan yang baik

6. Mengajarkan sikap disiplin pada anak

7. Mengajarkan nilai-nilai kejujuran pada anak 
8. Mengajarkan tanggung jawab pada anak

9. Mengajarkan anak untuk dapat berinteraksi dengan baik terhadap orang lain

10. Mengajarkan proses dan sikap berjuang untuk memperoleh sesuatu

Bagi orang tua khususnya ibu yang memiliki anak usia remaja, mereka mengungkapkan bahwa mereka memiliki tantangan tersendiri yang agak berbeda dengan para ibu lainnya yang memiliki anak dan belum memasuki usia remaja, yaitu bahwa anak mereka di usia remaja tidak mau menerima nasihat dari orang tua saat dinasihati dan anak remaja mereka merasa lebih tahu dari orang tuanya.

Dalam situasi yang demikian, orang tua harus mengembangkan pola-pola pengasuhan yang tidak kaku. Menurut para ibu yang menjadi peserta pelatihan dan memiliki anak usia remaja, strategi yang dapat dilakukan oleh orang tua terhadap anak remajanya adalah dengan cara:

1. Menjadi teman yang baik bagi anak remaja mereka

2. Orang tua harus lebih banyak ngobrol dengan anak usia remaja mereka

3. Orang tua harus dapat mencari waktu yang tepat untuk menyampaikan nasihatnya pada remaja

4. Mencari moment yang tepat untuk dijadikan contoh sebagai media untuk menasihati remaja

5. Tidak membandingkan anak remaja mereka dengan orang lain

6. Menanamkan pemahaman pada anak, bahwa tidak ada anak yang bodoh, tetapi setiap hal adalah pilihan dan akan ada konsekuensi serta perjuangan.

7. Memberi tanggung jawab pada remaja agar mereka belajar menjadi dewasa

Metode pelatihan brainstrorming dan sharing pengalaman di antara peserta sangat membantu ibu-ibu dalam pelatihan parenting ini, walaupun dari hasil pengamatan sebagian besar ibu-ibu peserta pelatihan merasa sudah mengetahui dan mengerti mengenai proses parenting. Hal ini dapat dipahami dari mobilitas penduduk Desa Pantai Bahagia selama ini lebih banyak melakukan mobilitas ke kota. Di sisi lain, pola interaksi warga Desa Pantai Bahagia dengan para pendatang sangat terbuka, lugas dan cair. Interaksi diantara berbagai faktor tersebut dapat menjadi pendorong terbentuknya parenting self-efficacy yang tinggi pada diri ibu.

\section{SIMPULAN}

Ibu sebagai orang tua yang lebih banyak menghabiskan waktu bersama anak terutama pada saat anak berusia masih kecil dan sebagai sosok yang memegang peranan sebagai pengasuh dan pendidik di dalam keluarga menjadikan ibu memegang peranan penting dalam keluarga. Dalam situasi demikian, seorang ibu dituntut memiliki pengetahuan mengenai tahapan perkembangan anak. Pola interaksi warga Desa Pantai Bahagia dengan para pendatang sangat terbuka, lugas dan cair. Interaksi diantara berbagai faktor tersebut dapat menjadi pendorong terbentuknya parenting self-efficacy yang tinggi pada diri ibu.

\section{DAFTAR PUSTAKA}

Bandura, A. (1977). Self-Efficacy: Toward a Unifying Theory of Behavioral Change. Psychological Review, 84, 2, 191-215.

Coleman, P. K. \& Karraker, K. H. (2000). Parenting Self-Efficacy among Mothers of School Age Children: Conceptualization, Measurement, and Correlates. Diakses dari http://www.jstor.org/stable/585698

Donovan, W. L., Leavitt, L. A., \& Walsh, R. O. (1997). Cognitive set and coping strategy affect mothers' sensitivity to infant cries: A signal detection approach. Child Development, 68, 760-772. 
Erikson, E. H. (1959). Identity and the Life Cycle. New York: International Universities Press.

Holloway, S., D., \& Behrens, K., Y., 2002, Parenting self-efficacy among Jamanese mothers: qualitative and quantitative perspectives on its association with childhood memories of family relations. New Directions for Child and Adolescent Development, 96, 27-43.

Hurlock, E. B. (1997). Perkembangan Anak. Alih bahasa oleh Meitasari Tjandra. Jakarta: Erlangga
Salonen, A., H., Kaunonen, M., Astedt-Kurki, P., Jarvanpaa, A., Isoaho, H., \& Tarkka, M., 2009, Parenting selfefficacy after childbirth. Journal of Advance Nursing, 65 (11), 24-36.

Santoso, Meilanny Budiarti dan Batubara, Megawati (2017) Assessment Kapasitas Ibu Dalam Membimbing Proses Belajar Anak Usia Sekolah Dasar (Studi Pada Ibu Sebagai Orang Tua Siswa Di SDN Hanjuang Samijaya Kelurahan Cihanjuang Kecamatan Parongpong Kabupaten Bandung Barat). Jatinangor. Universitas Padjadjaran. 